\title{
Evaluation of performance and suitability of rapid T.cruzi antibody tests for deceased organ donor
}

screening

Inês Ushiro-Lumb, Mhairi Webster and Alan Kitchen

Microbiology Services, NHS Blood and Transplant, Colindale, London NW9 5BG, UK

\section{Background}

- In the UK, the Advisory Committee on the Safety of Blood, Tissues and Organs (SaBTO) recommends that organ donors with risk of $T$ cruzi infection be tested for specific antibodies

- Identification of such risk is part of the donor characterisation

- Local pre-donation screening for $T$ cruzi antibody $(\mathrm{Ab})$ is not currently feasible as Chagas disease is rarely diagnosed in the UK and investigations are only performed in specialised laboratories

- Centralized deceased donor testing is currently undertaken at a NHS Blood and Transplant reference laboratory, with results available on the next working day post-donation

- Unlike assays for high throughput testing, rapid point of care tests are available as individual units, offering a potentially suitable option for laboratories needing to undertake low number of $T$. cruzi $A b$ testing solely for deceased organ donors

- Assays need to be evaluated for suitability and performance before incorporation in any testing algorithm

\section{Aim}

- To perform a preliminary evaluation of the performance of $T$ cruzi $A b$ rapid tests and their suitability for local pre-donation screening of deceased organ donors.

\section{Method}

- Six rapid tests were selected on the basis of published evaluated performance, CE marking, and availability in the UK (table 1).

- The assays were evaluated against a panel of 30 well characterised T.cruzi Ab positive samples from our sample repository and 26 performance panel samples (Seracare ${ }^{\mathrm{TM}}$ )

- Twenty samples from blood donors with no known exposure risk to $T$ cruzi and 3 samples from the above performance panel were used as negative controls.

\section{Results}

- Overall sensitivity of $94.6-100 \%$

- No specificity issues observed

- There were small practical differences, such as sample volume and test procedures, but all of the assays were considered suitable for use in the laboratory environment
Table 1: Evaluation of six rapid tests for T. cruzi antibody detection

\begin{tabular}{|c|c|c|c|c|c|c|c|}
\hline \multirow{2}{*}{$\begin{array}{l}\text { Sample type } \\
\text { Assay }\end{array}$} & \multicolumn{2}{|c|}{$\begin{array}{l}\text { Performance } \\
\text { panels } \\
\text { Seracare }^{\mathrm{TM}}\end{array}$} & \multicolumn{2}{|c|}{$\begin{array}{l}\text { Confirmed } \\
\text { cases } \\
\text { (non-UK) }\end{array}$} & \multicolumn{2}{|c|}{$\begin{array}{l}\text { UK blood } \\
\text { donors with } \\
\text { no risk } \\
\text { exposure }\end{array}$} & \multirow{2}{*}{$\begin{array}{l}\text { Overall } \\
\text { positive } \\
\text { score } \\
(\%)\end{array}$} \\
\hline & Pos & Neg & Pos & $\mathrm{Neg}$ & Pos & $\mathrm{Neg}$ & \\
\hline $\begin{array}{l}\text { Trypanosoma } \\
\text { Detect Rapid } \\
\text { Test * }\end{array}$ & $26 / 26$ & $3 / 3$ & $30 / 30$ & $0 / 0$ & $0 / 0$ & $20 / 20$ & $\begin{array}{l}56 / 56 \\
(100)\end{array}$ \\
\hline $\begin{array}{l}\text { Chagas Quick } \\
\text { Test * }\end{array}$ & $26 / 26$ & $3 / 3$ & $30 / 30$ & $0 / 0$ & $0 / 0$ & $20 / 20$ & \\
\hline $\begin{array}{l}\text { SD Chagas Ab } \\
\text { Rapid }\end{array}$ & $26 / 26$ & $3 / 3$ & $29 / 30$ & $0 / 0$ & $0 / 0$ & $20 / 20$ & $\begin{array}{l}55 / 56 \\
(98.2)\end{array}$ \\
\hline $\begin{array}{l}\text { Chagas Stat-Pak } \\
\text { assay }\end{array}$ & $24 / 26$ & $3 / 3$ & $30 / 30$ & $0 / 0$ & $0 / 0$ & $20 / 20$ & $\begin{array}{l}54 / 56 \\
(96.4)\end{array}$ \\
\hline $\begin{array}{l}\text { WL Check } \\
\text { Chagas }\end{array}$ & $25 / 26$ & 3/3 & $29 / 30$ & $0 / 0$ & $0 / 0$ & 19/20\# & $\begin{array}{l}54 / 56 \\
(96.4)\end{array}$ \\
\hline $\begin{array}{l}\text { Onsite Chagas } \\
\text { Ab Rapid Test }\end{array}$ & $24 / 26$ & $3 / 3$ & $29 / 30$ & $0 / 0$ & $0 / 0$ & $20 / 20$ & $\begin{array}{l}53 / 56 \\
(94.6)\end{array}$ \\
\hline
\end{tabular}

* Same assay provided by two different distributors

\# IgG control failed with one sample, so result was void

\section{Conclusion}

- We have performed an initial evaluation of a number of rapid tests for T.cruzi Ab for use in predonation screening of donors identified to be at risk of T.cruzi infection

- We have also scored the tests according to other parameters such as sample volume and ease of use (data not shown here)

- A small difference in sensitivity was seen across the tests, with no concerns around lack of specificity, making this an option for pre-transplant screening, ahead of the existing formal posttransplant screening in NTMRL

- Use of a rapid test for T.cruzi Ab at the time of testing organ donors for the mandatory markers of blood-borne infections would ensure that the required information on donor status is available at the time of donor organ offer

\section{Bibliography}

Guidance on the Microbiological Safety of Human Organs, Tissues and Cells Used in Transplantation; Advisory Committee on the Safety of Blood, Tissues and Organs (SaBTO), Feb 2011

Guidelines for the Blood Transfusion Services in the United Kingdom; 8th Edition, 2013 - Joint United Kingdom (UK) Blood Transfusion and Tissue Transplantation Services Professional Advisory Committee (JPAC) 